\title{
A Child and Nature
}

\section{Margaret Morse Nice}

To cite this article: Margaret Morse Nice (1921) A Child and Nature, The Pedagogical Seminary, 28:1, 22-39, DOI: 10.1080/08919402.1921.10532865

To link to this article: http://dx.doi.org/10.1080/08919402.1921.10532865

Published online: 30 Aug 2012.

Submit your article to this journal 준

LII Article views: 9

Q View related articles $\sqsubset$ 


\title{
A CHILD AND NATURE.
}

\author{
By Margaret Morse Nice
}

\begin{abstract}
"All things that are tame, are, as 1 t were, an incarnation of and embodiment of the littleness of men, but all things that are wild, are, as it were, a portion of the Deity."

$-A$ Draught of the Blue, F. W. Bain.
\end{abstract}

Some people are indifferent to nature, some care for tame animals or cultivated flowers, while comparatively few are true nature lovers. The indifferent ones may be so inherently or from lack of the proper stimulus; sometimes a friend, a course in biology or a book will rescue these individuals from their sad state, but others seem hopeless. Pet lovers lavish their affection on horses, canaries, garden, and so forth, and at the same time may care little or nothing about wild lifewitness the chronic battles between those who admire cats and those who prefer birds. Real nature lovers are of many degrees and kinds; some are specialists, being thrilled by mountains or entranced by dragonflies, while others include all outdoors in their affection. But they all agree in this: that nature, as she is, is fascinating and wonderful to them and to love and protect her is their privilege and duty.

Our first child is a nature lover of the most intense kind. She has shown such unbounded delight, quaint fancy and unexpected philosophy in this field, that I am moved to share my record with others that they may get an insight into a child's mind, and perhaps a new appreciation of the attractiveness of our humbler fellow creatures.

The question arises as to what part heredity, environment and training have played in such a case. With our child all of these factors have been favorable. Through heredity she seems to have received an innate bent in this direction; her relatives include nature lovers and pet lovers of varying degrees, while her father is a physiologist and her mother a biologist. However, no other member of her family, immediate or remote, has displayed so great a devotion to nature as hers. The development of this interest has been fostered by her environment: Oklahoma with its rich flora and fauna throughout most of the year, and the Pelham hills in Massachusetts during the summers. She has had many pets, most of them wild creatures. As for her training, she has heard 
and read much of the best nature literature from Kipling's "Jungle Books" to the files of "Bird Lore." We have given her opportunities and let her react to them; we omit officious instruction and encourage her to make her own observations and discoveries. Instead of answering many of her questions, we ask her what she herself thinks in order to guard against the danger of spoiling her fresh outlook on life. We avoid sentimentality, yet have not taught her to dislike anything but pests, nor to fear anything except poisonous snakes.

It does not follow that in every child with favorable ancestry, environment and training, an ardent love for nature will appear; for our younger children under practically the same conditions have shown this characteristic only in a moderate degree. Our eldest seems to have gathered in herself the quintessence of nature love from all her ancestors.

\section{EARTH AND SKY}

This child has not shown the keen interest in the phenomena of earth and sky that some children do; her specialty lies elsewhere. She is fond of playing in sand or dirt, of gathering stones, climbing rocks and wading in brooks, just as most children are; in these activities both love of outdoors and the element of experiment enter.

I have noted two of her observations on matters pertaining to the sky when she was barely three. One evening she happened to be up late and saw for the first time the lights of the town in the valley below. "Oh, look at all dose pwetty lights! I sink dey are parts of a sun."

Another day during a thunder storm she told us: "I like a sunder. I jump up and down. A woawing (roaring) of sunder is like wats (rats) and like wolves."

Perhaps her chief reaction to these phases of nature has been that of inquiry.

When four she asked: "What is air? How do people make air? What makes air ?"

"Where does a 'gy (sky) 'dop (stop) ?"

"I used to think the earth was just squashed bacteria," she volunteered when six. "Why?" I asked. "Because the grains were so small." "What do you think now?" I inquired. "You told me it was made up of crumbed rocks."

"The reason we can't see air is that it's white and hasn't any look."

"How did water ever get into the world ?"

Various problems have troubled her because of the notion she had received of heaven being in the sky. For instance, 
when four she asked me: "Mudder, how do angels manage about a wain (rain)?" "I sink dey are higher dan a wain. How high is a 'gy? How high is a moon?"

Like many children she seemed to consider the sky solid.

"How hard is a 'gy of heaven?"

When seven she inquired, "How can the angels and Jesus breathe so high in the sky?" She thought heaven might be on Mars.

I happened to tell her, when she was five, the story of Joshua's commanding the sun to stand still and she was plainly skeptical. "How could he shout up so far? That great height! Millions of miles. Besides, it hasn't any ears."

Later in speaking of the Norse gods, she remarked, "I should think gods, if they lived in the sky, would get scorched, burnt and frozen."

The heavenly bodies have stimulated her imagination to some extent. When four years old, she announced: "I was a giant and I swallowed the sun. I just made that up." When six she located an imaginary "Home" in a planet, and two years later had all sorts of remarkable countries in the stars, the moon and Mars. "I have a sun and moon of my own. Sometimes I shower down the snow."

At present, when nine, she has reached the age of generalizing on occasion. The mention of a pamphlet entitled "How to become independent in five years" started her on the following reflections.

"Everything depends on something else." "We have to have the earth to walk on, air to breathe, food to eat and water to drink. Don't you think those are the four most important things? Of course you have to have places to sleep and trees and grass. No animals could get along without trees and grass. Of course you'd have to have the sun and moon. And in winter you have to have fire."

"Why do we have to have the moon?" I asked.

"Well, you know how dark it was that night. I think it's much pleasanter to have a moon."

\section{FLOWERS}

Flowers have delighted her since babyhood, her interest in them being most intense just before she was four. At that time she knew the names of forty different flowers, usually remembering a new name after hearing it only once. I have never known another child of this age to take such pleasure in identifying every new flower found.

Her attitude towards flowers is largely love which expresses 
itself in enjoyment of their beauty; she seldom picks flowers, preferring to leave them in peace. Few problems occur to her in connection with the plant world; once she knows the name of a flower she has in general no more questions to ask about it. She experiments with wild plants each spring by transplanting them to our grounds. Cultivated flowers do not appeal to her as the wild ones do, nor does she care to have a garden herself.

She has talked little about flowers. Not until she was eight did she mention them in her stories; then she invented a "Flower Land, where the flowers are so thick they nearly smother the birds as they go through them."

Upon finding a mass of spring beauties, she said, "When they get way open, they deserve the name of morning star."

\section{ANIMALS.}

Animals of all kinds, especially wild ones, are this child's greatest interest in life. In analyzing her attitude toward them, let us first consider what it is not. She has shown no fear, no cruelty and very little dislike. She has never been afraid of anything in nature from spiders and snakes to lions at the circus. Some children have fear suggested to them by adults, while others seem to be fearful of various things instinctively, no matter how careful their parents may have been to encourage the opposite attitude. She is never unkind to animals; only once do I remember having to caution hershe was then three-to be more gentle with a rabbit upon which she excused herself by saying, "But lions be wough." She kills various insect pests but she never torments anything. She has, moreover, never shown aversion to any creatures; without exception she has been willing and eager to take them in her hands. Now she has learned to disapprove of various injurious species largely because she knows the harm they do.

Her constant attitude has been that of love; at first universal, but gradually growing more discriminating. This affection and absorbed interest induced observation and experiment; these in turn led to definite problems which she tried to solve or at least pondered over, and finally she made generalizations from her experience. At first love predominated, colored by imagination and expressing itself to some extent in observation and experiment. From the age of four the solving of problems was most important with her affection gradually becoming less catholic. Finally, from the age of six, all these factors are operative and used with increasing in- 
telligence while there is the added element of philosophizing from her experience and reading.

\section{LOVE}

"In the love of our people for nature lies the highest hope of the race."-Harriet Monroe.

A child's love for animals shows itself in an intense interest in them, a desire to watch them and sometimes a wish to get hold of them. There is often great pleasure in handling and fondling; an adult can understand this in case of a rabbit, but it is not so easy to realize the bliss of holding an earthworm, frog or horned toad. Pets sometimes make delightful playthings; many are docile enough to lend themselves to the child's wishes, yet they are always doing unexpected things; they are thus animated toys with endless possibilities. The child's imagination is active; he endows the little beasts with all sorts of human attributes and considers that they will like the things he does. It is in this that much of the charm of the little child's reactions lie-he is so trustful, he must believe that his overflowing love is reciprocated, whereas the older child is wiser from experience.

Most babies have a great interest in animals; often they show enthusiasm over the sight of them and sometimes fear. Our little girl showed this typical baby delight from a year to eighteen months; then she had her first pet and it was at once evident that her admiration of her humbler fellow creatures was more than common. The pet was a frog; the baby would chase him over the house, catch him and carry him about, trying various experiments such as putting a piece of bread to his nose. When it croaked she said, "Fwog sin'," and once she invited me to "Kiss fwog." On our walks she would try to catch crows and she enjoyed hearing the toad chorus from the swamps. When nearly two she played enthusiastically with some measuring worms, admiring them as they walked over her rompers and her hands. The first toad that she had ever seen she pursued and captured, announcing, "Home, Papa." A large spider that had its web on our verandah was an object of great interest, the child announcing one evening when the spider was late in arriving, "Baby so happy 'pidy come back again."

When she was two I said to her, "Listen to that blue jay calling." "Is dat a mudder b'ue jay callin' her baby ?" she wondered. Then she decided, "Dat is a baby b'ue jay callin' her mudder."

When two and a half she would watch a flock of hens for 
an hour at a time, a one-legged rooster having a special fascination for her. She used to go down on all fours on the sidewalks to study the comings and goings of ants.

When she was three, her affection was most unbounded, her admiration most naive. It was at this age that she apparently made her first acquaintance with angleworms as we were planting tulip bulbs, for she exclaimed, "Oh, look at dis cunnin' little 'nake." I told her what it was and she got it out of the ground and exhibited it to her baby sister with joy that was delightful to witness. "Dis is my angleworm. Would my baby like to p'ay wid him wight on dere? Would you like to get on here, dear little angleworm? Her fell off of here. I'm winding it awound my fingers. Ha-ha, her almost fell and I caught her. It's a nice angleworm and it's my pet. I mustn't hurt my angleworm." I found her another and she was more jubilant than ever. She put them on top of the go-cart when she wheeled the baby, but she decided they wouldn't like to go too fast. She carried them around in her hand for a long time and after a while we discovered that she had presented one to the baby! That evening she remarked, "Weren't my angleworms tame!"

Her unspoiled attitude toward these creatures was evident a few months later when she lay down in bed, saying, "I'm cuddling down just like a little worm."

I had told her the fable of the "Ant and the Dove" and she remarked, "A ant never bit me." "Yes," said I, " one bit you at Cambridge." "I wish I could go to Cambridge to see my dear ants," was her unexpected reaction. "I don't like to go away from my dear pets." "What pets?" I asked. "My dear ants." "There will be plenty at Amherst," I assured her and she said, "I will like them so much."

She was fond of moths; she would catch them and carry them about, bringing one to supper and nearly drowning it in the milk she poured out for its delectation.

She considered frogs very superior playthings. She would carry them about, have them swim in a basin of water, play in the sandpile, look out of the window, sit in a train of blocks, ride in her pocket, in a wagon, or on a rubber cat, go down the athletic slide and perform countless other activities. They had to watch the processes of dishwashing and cooking; once she held a frog over the washtub, saying, "He is lookin' in so pwoudly." I told her that she and I would make gingerbread. "A fwog will help," said she. She carried him into the study and inquired: "Why don't you wite, Fader? Little fwog wants to watch you." She built a house of blocks for him saying: "Dis is a 'mokedack (smokestack) for a fwog to 
cook. Would you like dis wandah (verandah), little fwog? It has a sandpile. Didn't you hear what I told you, dear little fwog?"

She was very happy over a big fat toad. "Do you sink he loves me very much?" "Don't you sink he loves me? See how he sits on my hand!"

She spent a blissful day with a tame setting hen, lugging her about for hours at a time and recapturing her from the nest each time she escaped. She looked after "Friendly's" welfare by poking her head into water and into the grain pan, and to amuse her gave her rides down the slide. "I love Fwiendly so much and her loves me. She is so happy to see me!"

She was entranced with the baby chickens in the spring. She told me this story about one that had just hatched and was peeping. "I told him, be bwave, chicken, be bwave. Don't cwy or eider you'll be a cwy-baby. Be happy and cheerful, little chicken, like a soldier. Den you can shoot your ememies."

She said the neighbors didn't want her to "Bodder a cow." "How were you bothering the cow?" I asked. "Oh, I was just amoosin' him." "How were you amusing her?" "Oh, I was p'ayin' jokes wid him."

When four years old she no longer lavished admiration on angleworms and ants, but turned her attention to somewhat higher forms of life.

Little red salamanders fascinated her; she held one in her hand singing to it thus:

\section{"Dear little sing \\ How I love you."}

She first saw horned toads at this time and was immediately attracted to the prickly little creatures.

"I love my little pet-my little pet horned toad. I love him as much as a wabbit." "Horned toads are terribly good." "He ate a green grasshopper. He sought it was as $\mathrm{f}_{\text {weet }}$ as a sugar plum." She sat in the hammock with one in her hand, improvising songs to him, but all that I recorded were the following lines:

"Sing, sing little toadie, You are so happy."

Bunnies are in many respects ideal pets far little children; they are so soft and hugable and harmless. When this child was four she had three rabbits, which she named White-Ball, Peach-White and Brown-Ears. She had many plays for them and planned still others-a party, a garden, a wedding and 
even dictated a letter to one of them. She often composed songs sitting in her rocking chair with a bunny in her arms. One song began thus,

$$
\text { "Little chucklin' Bunny." }
$$

Another went this way:

$$
\begin{aligned}
& \text { "This is a happy Bunny, } \\
& \text { Happiest in a world." } \\
& \text { "Fly, fly, Bunny dear, } \\
& \text { Fly, fly, sweet little dear, } \\
& \text { Bunny, Bunny, Bunny dear." }
\end{aligned}
$$

Bunnies were apparently the criterion of lovableness, for she said: "Mother, you are as dear as a rabbit. Father is as dear as a rabbit too." And on another occasion, "Baby is as sweet as a rabbit."

After this instances of such intense devotion became less common. Her admiration for her beloved toads was expressed in her remark about one when five, "It had a very sweet croak." When six she told us apropos of a big specimen: "She's all contented so long as she's in an open window. She's such a dear thing." She caught two toads, naming them "Stone-Fat" and "Chirpy-Hop"; she let them swim in the bath-tub puting in a vast amount of stones "to suit them." She planned that sometime she would live in a house in the woods: "It won't have any floor, but just grass growing on it and frogs and everything could come in. My bed would be of pine needles. Toads could come hopping in."

Her love is not yet diminished for, when eight, she came running into the house in the greatest excitement saying, "I have the two things I love best in the world-a toad and a baby dove." She still examines each water meter she passes and rescues any marooned amphibia. She found a tiny swamp tree frog and said, "Wasn't that an extraordinary treasure!"

When six she had a painted turtle which she and her sisters used as a character in their play with their toys, having it marry first a cat and then an iron mule. "I just love Turtley. I think he's darling."

At this time she admonished her sister as follows in regard to a pet rabbit: "Make it as happy as you can. We love it ; we love it very much."

When eight she was enchanted with a praying mantis, saying, "It has wings like a fairy."

Birds are rather too elusive to appeal to the very little child; he likes to handle and fondle his pets. Our daughter loves 
birds increasingly as time goes on; they are probably her favorites of the animal kingdom.

She had heard the expression, "Happy as a lark," and when three she asked me: "Are you happy as a English 'barrow (sparrow) ?" "I'm as happy as a cwow. Are cwows happy ?" "I'm as happy as a meadowlark."

When six she was invited to help pick cherries and said, "I'd rather have the robins have them than us." Perhaps, however, generosity towards the birds was not her sole motive.

She adopted a baby robin at this time and loved it more than any other pet she ever had. "I love Speckled Breast more than my baby."

Her interest in bird's nest is absorbing at present; she is such an agile climber that few trees can discourage her. Once she remarked: "Don't you think a dove's nest is lovely because it is so like camping? It would be so cool in summer."

When she was five and a half, she was given a puppy; she played with her a great deal and often rocked her and sang to her, yet the duty of feeding her charge never appealed to her. She did not become really devoted to her little dog as many children do. She is much less of a pet lover than a nature lover.

"Mystery and terror are instinctively associated with the serpent; myth and legend show that this tendency has existed since the dawn of the human intellect," says Wm. Scully. On this child's father's side there is united dislike of snakes, quite marked in her father, and natural enough as he was brought up where copperheads abounded. Her maternal grandfather had a great antipathy to these reptiles, her grandmother has no love for them but her mother and aunts rather like them. The first time this child ever saw a snake was when she was two; she was very anxious to get hold of it-it was a little one-and she asked in disappointment: "Why don't you let me touch it? I want a pet 'nake."

Later she had her desire; when five she had been sick and while convalescing had several little snakes in bed to entertain her despite her father's horror. When eight she told me: "I almost caught a little green snake but it got away and I nearly cried." "The thing that I want most in all the world is to catch a little green snake."

Lack of affection is plainly shown in her attitude toward flies-a result of our teaching. When three she announced: "I kill f'ies. I just 'quash 'em." Occasionally, however, her normal attitude at this age towards all creation reasserted itself and she would call them her pets and once I heard her say, "Dear little f'y, come here." 
The next year her sanitary zeal was so great that she said, "If I find a f'ies eggs, I will take a gun and shoot 'em."

As she grew older she became more fastidious.

When five she remarked: "I don't like to pick up grasshoppers. They're too wibbely-wobbely. They aren't pleasant to pick up."

Although at four she exclaimed when looking at a picture book, "Oh, my pet skunk," at six she remarked, "I love all animals, only skunks I don't think are so pleasant." "Don't you love skunks?" I asked. " Not so terrifically much."

By eight many of her first loves had come to be despised. I asked whether she liked all animal life and she answered, "Well, I don't care especially for moles." "Why ?" I asked. "Well, I don't see them."

I thought she had said moths and she agreed that she didn't care much for them for "they are too fat."

"I like sea animals and land animals."

“Do you like insects?" I asked.

"I like butterflies. They are so pretty. I like caterpillars pretty well. Some insects are so ugly. They aren't very interesting. They aren't pretty. I don't care for them."

"Do you like spiders?" I asked.

"I don't care for them. I don't think there's much to them. They aren't pretty. Of course they do good. They do make some pretty things-their webs and golden dew."

Some time later she remarked: "I haven't any love for angleworms. I don't like ants and I don't like spiders. I don't think they're beautiful. Big ants bite. I don't like flies. Spiders are mostly legs."

One day I asked her whether there were any things in the animal kingdom that she disliked. She answered:

"Well, I don't have a special love for any of the insects. But I think butterflies are very pretty, of course. I don't like worms; I simply don't like them. I don't like caterpillars. I like worms very much for food for birds; if they get eaten up it's all right, but if they don't they're awful."

I mentioned a caterpillar covered with cocoons we had seen some months before and she said:

"I don't like parasites; I think they're horrid. I think parasites are a mean set, don't you ?"

I asked her what things in nature she liked best of all.

"Oh, birds; they're so soft and sing so sweetly and do such amusing things sometimes. And rabbits, they're soft too. Of course I like toads, but I don't know how to tame them. They hip-hop away. Turtles are cross." 
"I like frogs and toads and turtles and monkeys and baby and you the best in the world." "Why do you like monkeys so much ?" I asked. "Oh, because they climb."

"I like either water animals or birds best. Frogs or turtles or birds." "Why do you like frogs so much ?" I asked. "Oh, it's fun to chase them."

"I think I'd like to be a swallow," she decided. "They have such lovely times flying and don't have much of a nest to make, and dip in the water."

Another day she remarked: "I love birds and I love other things too. I just love rabbits; they seem to have a charm for all children, especially little children."

As for the part that animals have played in this child's imaginations, they have been the very warp and woof of the stories she has told, for they have been the characters, and descriptions of their appearance and habits have been the themes. The birds and animals she has invented have usually been curious creatures, surprising combinations of what occurs in real life. She has occasionally pretended to be an animal, sometimes a fox and again a toad with a thousand babies. When eight, she and her sisters and a boy playmate organized a "Monkey Family" whose chief occupation was climbing trees and on roofs of houses. Since they were monkeys, lessons were entirely inappropriate. All the tribe had special names; the baby was "Heideda" and was counted "the wisest of the band for she can talk the bird language and no one can understand her." Our eldest announced, "I'd rather be a monkey than a queen."

\section{INQUIRY}

"The mind seeks for truth as the body for food."-C. F. Hodge.

This child has naturally an inquiring mind, a scientific bent that many children lack. First came observation; in babyhood everything was a field for discovery; as she grew, more was taken for granted yet in cases where she is interested her powers of observation are increasingly keen and discriminating. Experiment appeared soon after; a large part of her activities with animals would come under this head-putting them in different situations to see what they would do, stimulating them in various ways and watching their reactions, yet all done in a spirit of friendliness and consideration, taking care not to hurt them in any way. Since animal life has such an interest for her, it was but natural that many problems should arise in her mind and that she should try to solve them by close observation and experiment. 
When nearly three she asked me about some English sparrows that were near a knot hole in a tree, "Do dey 'gratch (scratch) a hole wid deir bills, is dat a way?"

When she was three we caught some snails for our acquarium and she used to watch them, taking them out and arranging them along the window sill. "Two look if dey were kissin' deyself!" she exclaimed. Then she inquired: "What is inside of 'nails?" “Do 'nails love people?". I asked her for her opinion and she decided that they must love each other and their babies.

Sometimes she made an exciting discovery about her frogs. "Dey have moufs. Why do fwogs have moufs?" "It has two little eyes just like my baby. It has two eyes like oder people."

Other problems that presented themselves to her were:

"Why don't hens have fwont legs?"

"Do hens have minds?"

"Do horses talk?"

" How does a grasshopper sit on eggs?"

The next year, bacteria seem to have exercised her mind.

"Why are those little plants called bacteria? Because they're bad ?"

"Why do bacteria like to make people sick? Do dey get up at night and s'eep by day ?"

Her rabbit was eating some bread that had fallen on the floor and she inquired, "Why don't animals mind about bacteria?"

When looking at an "Economic Entomology," she asked whether a certain cutworm was bad and I told her that all cutworms were bad. She wondered, "How do some animals grow to be so bad?"

"Does a train run faster than a chicken?" “What do you think ?" I asked. "I think a chicken can go faster. I remember a train went rather slowly-bumpety, bump." She had not been on a train for half a year but the speed of chickens was a practical, everyday matter with her.

When five she concocted the following ingenious scheme: "I'll tell you another adventure I had. I saw a big black rat under a juniper." "If you tried poison ivy growing around the rat's hole would they get poisoned when they touched it? If you caught one, you could cut off his fur, couldn't you? You might have some poison ivy right by his hole, and he might get poisoned if he came out."

She had been studying a spotted turtle and said: "You 
notice how the shell all goes together. How do you suppose he creeped in?"

She caught another turtle and observed: "She can scratch herself with her hind legs, that is how she protects herself. Doesn't she seem to be a friendly one? Surely a snapping turtle couldn't be so friendly. Doesn't she have pretty legspretty legs and arms! Have you noticed what tiny spots she has on her skin and what big spots on her head?"

"What's the use of his great bones if he doesn't bite?" " He bites his food," I said. "I should think his food would be soft," and I had to agree as the books said they eat largely plant food.

"The turtle would seem like a mountain to a fly."

“Flies don't know about bacteria, do they ?"

I was telling her one evening to listen to the crickets. "Do they sing for joy because night has come?"

"The liveliest toads are always the ones we've just caught." "Why?" I asked. "Because they get so discouraged. They have such a time getting loose."

This summer she found a wren's egg and was all agog to hatch it; the only way she could think of was to hold it in her hand, but after a while she apparently grew weary and left it sunning in a window. The next year, when six, she got an English sparrow's egg and tucked it under some baby wrens so they could hatch it, her zeal for a baby bird making her forget temporarily her disapproval of English sparrows.

When she was shown a caterpillar covered with the cocoons of parasites, she asked, "Why doesn't he turn around and bite them off?"

We found an advertisement of a Frog Farm, the idea of which greatly appealed to the little girl. I told her some frog farms did not succeed because the big frogs ate their children. "But what do they think they are?" she asked. "Why doesn't a frog sit and watch its eggs sometime?"

When talking of black snakes getting some young robins she had been watching, she remarked, "Birds like themselves a little better than their babies, don't they ?"

"Since robins like civilization so much, why do they shriek so when people come to their nests?"

"How did life start ?"

She was looking at pictures of "game hogs" in Hornaday's "Our Vanishing Wild Life" and she could not understand why people shot birds. "Why do they shoot them if they don't care about them? Don't they dislike them?"

The next year she was fond of catching butterflies in her hands and playing with them gently. "The morning is my 
favorite time to catch butterflies." "Why?" I asked. "Oh, they aren't so very merry then. It's cooler."

When eight, she had some guinea pigs for pets and she observed them closely. "They go more by scent than by sight." "Do you know this one chews just like lightning? He chews perfectly as fast as lightning."

She remarked about a big fat toad: " $\mathrm{He}$ has such billowy sides. I'm glad I'm not so different on my two sidesso yellow on one side and so brown and warty on the other."

Upon seeing some chimney swifts, she said: "I call them arrows. Don't you think they look like bows and arrows?"

She had been reading of a father kingfisher sitting on his eggs and said: "We couldn't be heavy if we had to sit on our babies-on eggs. How could they get out without anything hard to push with-just faces? We'd have to help them."

When nine she said: "I don't see how people can love cats. Why don't they turn their attention to darling little rabbits? They're much softer."

"To think of people that keep cats that kill birds having the honor of a mockingbird's nest on their house!"

"Birds can't laugh, can they?" I said they seemed to express their joy by singing. "How do sparrows show their joy?"'

Although angels do not properly come under the head of nature, yet, as this child has compared them to natural objects, her ideas regarding them are of interest. When three years old she told me: "Angels are like birds 'cause dey f'y. Dey have diffwunt mouvs like birds. Birds have good mouvs, but angels have mouvs like me and my baby and my fader."

When eight she objected to angels because they had both feathers and hair-her sense of biological fitness being outraged. She did not see how they could sit down with comfort nor how the god of love could lie down with wings sprouting out. Later she criticized angels because they "are half people and half bird." "In one way devils are better because they aren't two things."

\section{PHILOSOPHIZING}

"Experiment is always at the bottom; . . . reason at the end." The Message of Leonardo-Geo. Sarton.

Being a thoughtful child, loving nature and yet not satisfied with the conditions of life either for herself or for the birds and animals, she has made generalizations and drawn conclusions that have much of the nature of philosophy about 
them. The injustice of the treatment accorded valuable wild species has troubled her as it has many another.

Philosophizing did not appear until she was six. The problem of people versus animals seems to have engrossed her attention.

"I don't like to destroy wild life. Why do people shoot little birds without pity?"

"I like animals better than people. They're more interesting than people."

"I don't see why we are so important-more important than any other animal. We have strikes and fights." I asked her whether she would like to be a toad as much as a child and she said, "Yes." She would also like to be a turtle. but not a bee, because bees die too soon.

"Birds are more intelligent than people about flying."

She remarked that one difference between people and other animals was that animals' legs come out as people's do when they're sitting down. Another difference is that animals are covered with fur. People are hardly a bit like trees. When $I$ asked whether they were alike in any way, she said their leaves were something like hands.

She was noticing the position of a butterfly's legs and speaking of how it balanced itself. "Butterflies' wings are very large in comparison to their bodies-that is why they can fly so well. Our hands are tiny in comparison to our bodies. Birds' wings are just right."

She was playing with an old hat of mine decorated with roses and her four year old sister said: "Why does father have to have a black hat? I'd like him to have a rosy hat, a big, rosy hat." "I wouldn't," said the six year old. "In most animals males are most beautiful. Most females are brown, for instance, birds. I don't like to have males most beautiful all the time."

She thought monkeys, frogs and toads were nearly related to us; monkeys because they look so much like us except their faces. But donkeys aren't much related to us: "Think of their ears!"

She didn't see why people had to wear clothes; she would prefer to be more like monkeys. "Why don't people have tails?" "They would help in climbing and in holding on to things."

As we were getting ready for a call, she said, "I'd like not to see any people, just animals." She would live off in the woods and climb trees and watch animals and write books about them. 
"Why are we so different from animals? Animals don't seem to have their eyes in their face."

"I don't know what people are made for. I suppose to make the world better. And sometimes they make it worse. Spend some of their energy making it worse and some of their energy making it better. Think of their fighting! If there weren't any people think how many passenger pigeons there would be. People who aren't any use! Isn't it a great sorrow!"

When seven, speaking of a wasp's nest that had been destroyed, she said: "They are as nice as you. Animals are as nice as people. Why do we live?" I asked what she thought and she answered, "For pleasure and unhappiness."

"Deer and birds are alike in one way because they both eat food. They are alike because their clothes grow on them."

"People are animals that don't have tails. Most animals have tails."

"I wish nature hadn't let man discover guns and then he couldn't have shot the birds."

"The trouble with nature is the pests. Everything has its pest. We have gnats and mosquitoes."

When she was eight she heard someone make the statement that there were too many people in the world. "Yes," she agreed. "They are killing off all the animals."

"Why did people kill the passenger pigeons?" "I don't think people are half as nice as animals." "I think people do more bad than good."

"If people only had wings and a tail that would be all they'd want."

"Baby is like an animal because she doesn't understand what we say."

"You know I like animals better than people. I like them better than white people any way for they make so much trouble wherever they go." Her distinction here was between white people and Indians, the attitude of the latter towards nature meeting with her approval.

I was trying to induce some interest in her despised number work by telling her how our civilization was dependent on arithmetic, but she had an answer ready: "Civilization has killed off so many animals that I'm quite disgusted."

"If nothing ever died, you couldn't walk anywhere without stepping on something alive."

As we were picking black-caps, she mentioned the white on them, something I had never noticed before. "In our life the youngest are the softest, but in the raspberry's life the youngest are the hardest." 
"I call snakes mostly tail."

"I wish meat came from plants. People have to kill things. If potatoes came from toads-that wouldn't be very nice."

"I think one reason animals fear fire is that they can't handle it. Only monkeys could; the others don't have the right kind of paws."

"You can't tell real animal stories, can you? You can't tell what the animals think."

"Why don't animals own themselves? Why do these apelike animals without any tails and funny fur and long hair have the say about them?"

"Why do people think they're so precious and not the animals? Except the animals they buy themselves-for instance, cows?"

"Do you think animals are as precious as people?" I asked.

"Why not? People are a kind of animal."

"What about leeches?" I inquired.

"Well, hunters act the same way."

When she was nine I asked her whether she thought people or animals were nicer.

"They're just the same," she answered. "Some animals are nicer-like rabbits-because they don't get up terrible wars."

"I don't see why animals don't have as much right to live as we do."

"What animals, for instance?" I asked.

"Beavers-and nice animals around-and doves."

"What about mosquitoes?" I suggested.

"I said animals. Of course I wouldn't mind killing off parasites. But I think it's just horrible to kill quail and other nice birds and just kill them for merely fun-like a weasel."

"I should think people would learn to look out and not do as they did with passenger pigeons."

"It might be nice to shoot if you're doing good, but just to shoot and shoot!"

Another time she said: "I suppose some animals think our babies and we-because we haven't any hair-are hideous !"

"I don't think it's nice to go on wanton slaughter. If you feed a thing and give it nice things, then you'd have some right. But if a thing is wild and doing lots of good-. I don't call it bad to step on a green worm that's eating up your plants." 
"They never pay any attention to the orphan birds, but just jump and do it any time."

When on a walk we heard a gun shot, and this lover of nature said, "I hate to hear shooting. It means death and death and death."

"Flowers fade away when you pick them. Birds are much more beautiful alive than dead. I wouldn't kill a robin for six hundred dollars. They're just as precious as anybody else." 